\section{Case Reports in Neurology}

Case Rep Neurol 2020;12:106-109

DOI: 10.1159/000500950

Published online: December 14, 2020
(C) 2020 The Author(s)

Published by S. Karger AG, Basel www.karger.com/crn

This article is licensed under the Creative Commons Attribution-NonCommercial 4.0 International License (CC BY-NC) (http://www.karger.com/Services/OpenAccessLicense). Usage and distribution for commercial purposes requires written permission.

\title{
Streptococcus pneumoniae Meningitis and Intracranial Vasculopathy: Clinical Correlation with Improving Transcranial Doppler Hemodynamics
}

\author{
Mohamad Imran Idris Sharon Mei Ling Tai Chong Tin Tan \\ Kay Sin Tan \\ Division of Neurology, Faculty of Medicine, University of Malaya, Kuala Lumpur, Malaysia
}

\section{Keywords}

Meningitis · Streptococcus pneumoniae · Transcranial Doppler

\begin{abstract}
Streptococcus pneumoniae are Gram-positive bacteria that are responsible for many types of illnesses including pneumonia, sinus infections, and community-acquired meningitis. One important complication of bacterial meningitis is intracranial vasculopathy. Possible etiologies include vasculitis, vasospasm, endocarditis, or intra-arterial thrombosis. We present a case report of S. pneumoniae meningitis treated with antibiotics in which clinical improvement correlated with serial transcranial Doppler ultrasonography (TCD) improvement, suggesting vasospasm or vasculitis as a possible mechanism for intracranial vasculopathy.
\end{abstract}

(C) 2020 The Author(s)

Published by S. Karger AG, Basel

\section{Introduction}

Streptococcus pneumoniae, or pneumococcus, are Gram-positive bacteria that are responsible for many types of illnesses including pneumonia, meningitis, as well as ear or sinus

\begin{tabular}{ll}
\hline & Mohamad Imran Idris \\
Division of Neurology, Faculty of Medicine & University of Malaya \\
Kuala Lumpur, 50603 (Malaysia) & imranidris@um.edu.my
\end{tabular}




\section{Case Reports in Neurology}

Case Rep Neurol 2020;12:106-109 DOI: 10.1159/000500950 2020 The Author(s). Published by S. Karger AG, Basel www.karger.com/crn

Idris et al.: Streptococcus pneumoniae Meningitis and Intracranial Vasculopathy: Clinical Correlation with Improving Transcranial Doppler Hemodynamics

infections. They are spread via several routes such as coughing, sneezing, or close contact with an infected person. S. pneumoniae are the most common pathogen in cases of community-acquired meningitis [1]. These cases may present with fever, stiff neck, headache, confusion, and sensitivity to light.

Intracranial vasculopathy is an important complication of bacterial meningitis. It increases the risk of stroke and negatively affects prognosis. It is also a common phenomenon, occurring in $37.1 \%$ of patients with bacterial meningitis according to one study [2]. Many possible etiologies have been identified including vasculitis, vasospasm, endocarditis or intra-arterial thrombosis [3]. Transcranial Doppler (TCD) ultrasonography is a non-invasive approach to detect intracranial vasculopathy and can identify patients at risk of stroke from the underlying infection $[4,5]$. We present a case report of Streptococcus pneumoniae meningitis treated with antibiotics in which clinical improvement correlated with serial TCD improvement.

\section{Case Report}

A 50-year-old man presented with 2 days of fever, confusion and left-sided body weakness. On examination, he was febrile, confused and had left-sided hemiparesis. MRI brain (Fig. $1 \mathrm{a}, \mathrm{b}$ ) demonstrated right frontal cerebritis with acute infarcts in both basal ganglia. MRA (Fig. 1c) revealed generalized irregularities in the M1 segments of both middle cerebral arteries (MCAs). Lumbar puncture showed elevated polymorphonuclear leukocytes with low glucose $(0 \mathrm{mmol} / \mathrm{L})$ and high protein $(4.9 \mathrm{~g} / \mathrm{L})$. Blood and CSF cultures grew S. pneumoniae. The patient received 42 days of antibiotics (intravenous Ceftriaxone $2 \mathrm{~g} \mathrm{BD}$ ). Antibiotic treatment was extended to 42 days in this case to cover for the possibility of the right frontal cerebritis (seen on MRI brain) developing into an abscess. The patient also received intravenous dexamethasone $24 \mathrm{mg}$ BD for 4 days beginning on day 8 of his illness. A repeat MRI/MRA brain showed some resolution in the cerebritis and intracranial vasculopathy seen previously (Fig. $1 d-f)$.

TCD on day 10 (Fig. 2, left column) of antibiotic treatment demonstrated high mean flow velocities in the right MCA (range 181-202 cm/s), right anterior cerebral artery (ACA) (range $129-154 \mathrm{~cm} / \mathrm{s}$ ) and the intracranial portion of the right internal carotid artery (ICA) (range $123-136 \mathrm{~cm} / \mathrm{s}$ ). Repeat TCD on day 42 (Fig. 2, right column) of antibiotic treatment demonstrated significant reductions in mean flow velocities: right MCA 56-65 cm/s, right ACA 87$91 \mathrm{~cm} / \mathrm{s}$, and right ICA $25-30 \mathrm{~cm} / \mathrm{s}$.

After discharge from the ward, he continued to improve and was subsequently deemed to be able to carry out daily activities independently.

\section{Discussion}

Intracranial vasculopathy that is seen in cases of bacterial meningitis can be due to several mechanisms, including vasospasm, vasculitis, or intra-arterial thrombosis. In many patients, it is often difficult to match any intracranial vasculopathy seen on imaging with its underlying mechanism. This case report illustrates one way in which TCD can be used to determine the cause of intracranial vasculopathy in individuals with bacterial meningitis.

\section{Karger'=}




\section{Case Reports in Neurology}

\begin{tabular}{l|l}
\hline Case Rep Neurol 2020;12:106-109 \\
\hline DOI: 10.1159/000500950 & $\begin{array}{l}\text { ( ) 2020 The Author(s). Published by S. Karger AG, Basel } \\
\text { www.karger.com/crn }\end{array}$ \\
\hline
\end{tabular}

Idris et al.: Streptococcus pneumoniae Meningitis and Intracranial Vasculopathy: Clinical Correlation with Improving Transcranial Doppler Hemodynamics

Reduction in TCD velocities coupled with improvements on MRA with antibiotic treatment suggest that vasospasm/vasculitis may have been responsible for the changes that were originally seen. This case report also illustrates the utility of TCD in guiding further neuroimaging, with disturbances in TCD hemodynamics reflecting abnormalities seen in the patient's MRA. Going forward, improvements in TCD hemodynamics may be a useful surrogate marker for treatment trials involving patients with bacterial meningitis.

\section{Conclusion}

Antibiotic treatment for S. pneumoniae meningitis correlated with improvement in clinical status and TCD hemodynamics. Serial TCDs may be a potentially useful strategy in the management of bacterial meningitis.

\section{Acknowledgement}

No other persons or organizations have made significant contributions to the manuscript.

\section{Statement of Ethics}

Written informed consent was obtained from the patient for publication of this case report and any accompanying images.

\section{Conflict of Interest Statement}

The authors have no conflicts of interest to declare.

\section{References}

1 Durand ML, Calderwood SB, Weber DJ, Miller SI, Southwick FS, Caviness VS Jr, et al. Acute bacterial meningitis in adults. A review of 493 episodes. N Engl J Med. 1993 Jan;328(1):21-8.

2 Pfister HW, Borasio GD, Dirnagl U, Bauer M, Einhäupl KM. Cerebrovascular complications of bacterial meningitis in adults. Neurology. 1992 Aug;42(8):1497-504.

3 Klein M, Koedel U, Pfefferkorn T, Zeller G, Woehrl B, Pfister HW. Arterial cerebrovascular complications in 94 adults with acute bacterial meningitis. Crit Care. 2011;15(6):R281.

4 Tai MS, Sharma VK. Role of Transcranial Doppler in the Evaluation of Vasculopathy in Tuberculous Meningitis. PLoS One. 2016 Oct;11(10):e0164266.

5 Lu CH, Chang WN, Chang HW, Chung KJ, Tsai NW, Lui CC, et al. Clinical relevance of intracranial arterial stenoses in tuberculous and cryptococcal meningitis. Infection. 2007 Oct;35(5):359-63. 


\section{Case Reports in Neurology}

\begin{tabular}{l|l}
\hline Case Rep Neurol 2020;12:106-109 \\
\hline DOI: 10.1159/000500950 & $\begin{array}{l}\text { @ } 2020 \text { The Author(s). Published by S. Karger AG, Basel } \\
\text { www.karger.com/crn }\end{array}$ \\
\hline
\end{tabular}

Idris et al: Streptococcus pneumoniae Meningitis and Intracranial Vasculopathy: Clinical Correlation with Improving Transcranial Doppler Hemodynamics
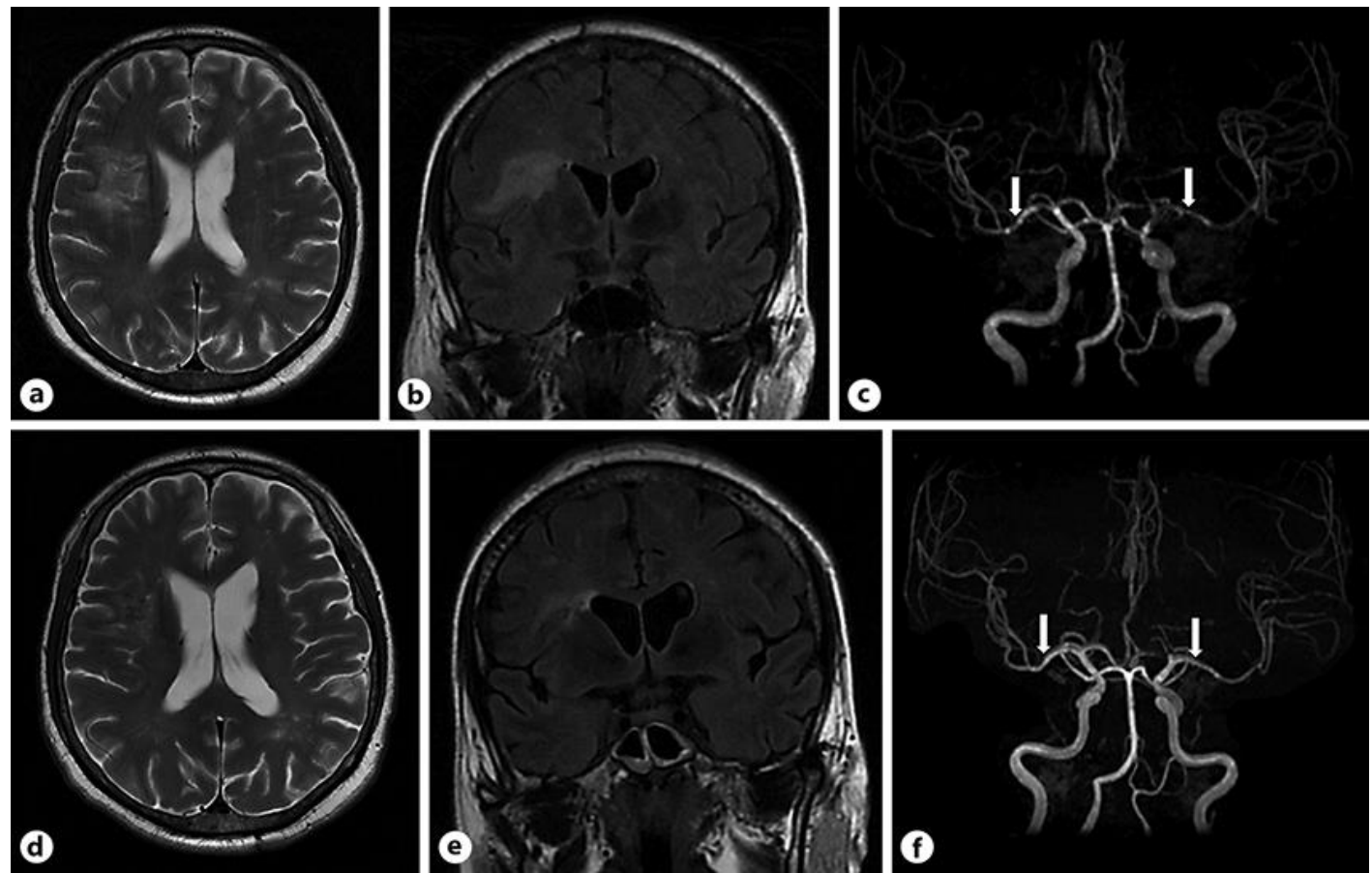

Fig. 1. Top row: a T2-weighted and $\mathbf{b}$ FLAIR sequences before treatment with antibiotics showing right frontal cerebritis. c MRA demonstrating generalized irregularities in the M1 segments of both MCAs (arrows). Bottom row: $\mathbf{d}$ T2-weighted and e FLAIR sequences showing resolution of the previously seen right frontal cerebritis. $f$ MRA demonstrating attenuation of the irregularities previously seen in the MCAs (arrows).

Day 10
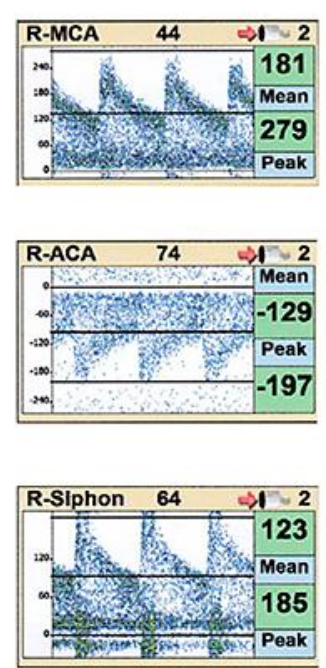
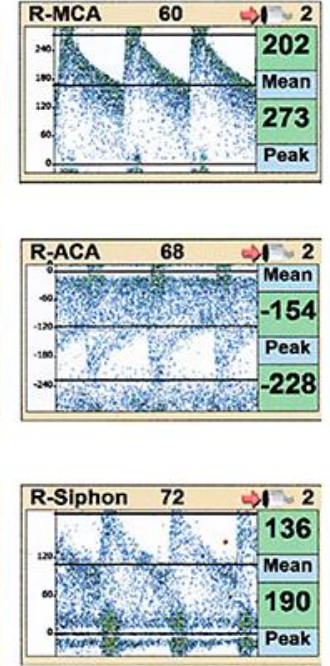

Day 42
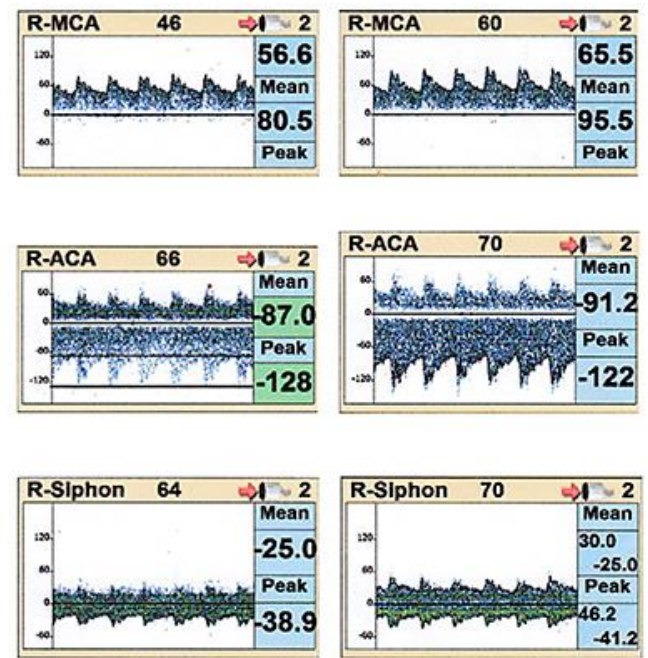

Fig. 2. Mean flow velocities on day 10 (left column) and day 42 (right column) of antibiotic treatment. 